\title{
Training Strategies for Applied German-speaking Talents in the "One Belt One Road" Initiative
}

\author{
Junliang Ji* \\ Jilin Engineering Normal University, Changchun 130052, Jilin Province, China \\ *Corresponding author: Junliang Ji, JJL239@126.com
}

\begin{abstract}
Under the "One Belt One Road" initiative, China and Germany have become closer in cooperation and have made substantial progress in the fields of economy, trade, culture, science, and technology. The close cooperation between China and Germany has raised the demands for diversified German-speaking talents. After years of development and continuous exploration, China's educational institutions with German majors have established a mature talent training model but it is not enough to meet the country's growing demands for applied talents along with the economic development. With the advancement of the national education reform, many majors in various schools are thinking of reform plans suitable for their own development. Although German as a "minor" language major is not very widely used, it plays an active and effective role in China's trade and cultural exchanges. Hence, there is a need to comprehensively improve students' overall quality, advocate diversified training methods, adopt German-English bilingualism and professional German teaching methods, increase the cooperation of education between companies and institutions, as well as strive to train more applied Germanspeaking talents for the country.
\end{abstract}

Keywords: One Belt One Road; Applied German-speaking talents; Talent training strategy; Compound bilingual; Cooperative education

Publication date: July 2021; Online publication: July 30, 2021

\section{Introduction}

The "One Belt One Road" initiative has been implemented by China, benefiting the lives of people all over the world. With the rapid progress of the "One Belt One Road" initiative that can be seen in China-Europe Railway Express, China-Pakistan Economic Corridor, Hungary-Serbia Railway, China-Myanmar Oil and Gas Pipeline Project, Port of Piraeus in Greece, as well as Zambia-China Economic and Trade Cooperation Zone, there is a surging demand for minor language talents. However, the supply of these talents is in a state of emergency. These so-called talents are those who have a certain degree of professional knowledge or specialized skill, perform creative work, contribute to the society, and are workers with high quality and skills in human resource. Therefore, the goal of national talent training is no longer restricted to the traditional research talents but caters to the urgent need for a large number of applied talents. Specific to the German teaching work, it is the language teaching that emphasizes on the application, communication, and exchanges. Under the background of mass education, it emphasizes the core courses and nurturing of applied talents.

The "One Belt One Road" initiative has an urgent demand for language talents. In 2013, China proposed the "New Silk Road Economic Belt" and the "Maritime Silk Road" initiatives which are collectively referred as the "One Belt One Road" initiative. This initiative has effectively promoted the development of regional economy and at the same time, it has been promoting the orderly progress of China's economy. Therefore, in order to better support China's economic growth, colleges and universities 
need to reform foreign language teaching and nurture more professional and practical talents so that students do not only have solid language skills but also have a certain economic thinking and innovative idea, eliminating the shackles of traditional education model of thinking and eventually contributing to the economic development of China.

In the context of the "One Belt One Road" initiative, due to more frequent exchanges with countries along the route and wider economic cooperation, it is necessary to increase the training of professional language talents that meet the requirements of project developments in order to build a more comprehensive humanistic road. Language talents in the new era need to have a few characteristics. First, language talents have to be compound talents. They do not only need to have good language application skills but they also need to have relatively solid basic knowledge, good expression skills, a high level of international vision, and the ability to master the laws of economic development. Secondly, they need to have innovative capabilities. Generally speaking, language talents are not only required to have solid professional knowledge but also, excellent innovative and thinking skills. Finally, as the "One Belt One Road" initiative involves many countries, different countries have different customs which require foreign language talents to have good cultural literacy where they are able to accept and understand the customs and culture of other countries. Only in this way can they effectively prevent misunderstandings caused by problems in comprehension of a language. In order to train language talents to meet the development needs of this initiative, Chinese universities need to conduct language teaching in a targeted manner and strive to improve the overall quality of students.

\section{Necessity of training applied German-speaking talents}

Currently, foreign language teaching is undergoing tremendous changes. The emphasis on mass education in the past has evolved into focusing on the current requirements to improve the overall quantity and quality of students. It is necessary to nurture new types of talents who can meet the social requirements. German is a minor language, however China's demand for German-speaking talents is increasing day-by-day. The exchanges between China and Germany need to rely on more German-speaking talents to build a bridge in communication. The former Vice Premier of the State Council, Li Lanqing had emphasized countless times in his speech that it is necessary to train high-level talents with professional skills as well as foreign language skills. The talents mentioned here must be those who can cope with social challenges, master professional knowledge, and proficiently use foreign languages. University teachers need to consider on how to ensure German language majors have certain degree of competitiveness and social adaptability as soon as they leave their schools. By renewing the concept of running a school and establishing a tertiary education concept with employment, market-oriented, knowledge, skills, quality-oriented, student-centered, and quality education as the goals in addition to practical skills and innovative ability training as core teaching philosophies, the curriculum system should be redesigned and some courses should be appropriately added according to the changing situation while maintaining its own characteristics and taking into consideration of the traditional advantages.

\section{Current employment situation of German majors}

On the one hand, the current employment situation is severe. Up to now, more than 70 schools are offering German majors, even engineering colleges have also joined the ranks in offering this major. In this way, there would be excessive talent training and a mismatch between students' abilities and the social needs. Many students have difficulties in finding ideal jobs after graduation or have limited internship opportunities during their studying period. On the other hand, China and Germany have close collaborations and there are large opportunities for exchanges and cooperation. These require many German-speaking 
talents especially those with certain professional backgrounds and practical skills. Such talents provide productivity and contribute to the society while meeting the needs of internationalization and adapting to the development of the times. From the contradictions between these two views, a problem is revealed. To a certain extent, some students that have been trained do not have advantages in employment or meet the social needs. Hence, the concepts and models in the training of applied German-speaking talents need to be changed to explore a new way of training.

\section{Current status of the socials needs for German-speaking talents}

The smooth implementation of the "One Belt One Road" initiative requires language as the basis for development which in turn, requires talents. Therefore, it all boils down to the training of language talents. There are many countries involved in the "One Belt One Road" initiative. The proficiency of the languages belonging to these countries along the route is an important factor to strengthen communication and cooperation. Therefore, with the continuous progress of the "One Belt One Road" initiative, there is an increasing demand for different languages, especially the German language.

Both the traditional industries and emerging industries have great demands for German-speaking talents. First of all, with the continuous progress of the "One Belt One Road" initiative, it has brought considerable advantages to China's equipment manufacturing, electric power, and other industries. As the state encourages these companies to cooperate with Germany in the field of resources and infrastructure construction as well as to continuously increase the efforts in mergers and acquisitions of overseas technology-based companies, there is a possibility of promoting the cooperation between China and Germany if they are able to meet certain standards in communication skills in addition to their strong professional capabilities. The current "German + profession" talent training is by combining foreign language skills and professional capabilities which is of great significance to China's effective implementation of the "One Belt One Road" initiative.

Secondly, the smooth implementation of the "One Belt One Road" initiative requires a large number of German-speaking talents with international vision. German culture is different from the Chinese culture and these cultural differences lead to different ways of thinking in problem-solving. Therefore, learning German well is not good enough but the sincerity of forging greater cooperation between China and Germany as well as expressing the awareness of respect for the German culture can better promote the smooth implementation of the "One Belt One Road" initiative.

Lastly, the "One Belt One Road" initiative still requires high-level, high-standard, and high-end language talents. German is one of the most important foreign languages and only professional foreign language-speaking talents can provide high-standard foreign language services. Therefore, the "One Belt One Road" initiative particularly needs foreign language-speaking talents with a good command in German.

\section{Training strategies in nurturing applied German-speaking talents}

There is a need to construct a talent training system that is focused on practical skills. The training of applied German-speaking talents is a systematic framework project which requires the consideration of various factors. The first is to emphasize practicality. The program needs to be promotable and developable. As the most active training factor, there is a need to exert subjective initiative during the training process and make good use of elective courses as a medium to provide students with opportunities to learn, practice independently, and expand their cultural domain knowledge in many ways. The second is to strengthen the training of students' basic skills by attaching importance to the five skills which are listening, speaking, reading, writing, and translation. In emphasizing quality education and application skills training, there is often a lack of basic skills training which easily expose these students of their shortcomings in their future 
German language applications and work. Therefore, strengthening the training of students' basic skills is the foundation of talent training. The third is to provide relevant courses to broaden students' horizons. In this case, students would focus on basic training in the first two grades and subsequently, focus on the cultural aspects in the third and fourth grades. Only by understanding the regional culture of Germany, then only there will be a breakthrough of the barriers in communication. The fourth includes the adoption of a distinctive German language talent training model, value the building and investment in teachers, seek out experienced staff from collaborating enterprises, and emphasize the comprehensive application skills of the school to nurture talents. Students are not only a receiver of knowledge but they also function as disseminators of knowledge. Students can use language as a carrier to lay a solid foundation for it and expand their personal development direction.

In order to improve the comprehensive quality of students in an all-rounded way, teachers should pay attention to the cultivation of students' comprehensive quality when imparting knowledge pertaining to the German language. By using books as a blueprint, teachers should continuously integrate new teaching contents, adopt flexible as well as diverse education and teaching methods to improve students' participation, as well as inspire students to think and explore during their learning. Teachers can also make full use of the advanced experience in discussion-based learning to strengthen the interactive model of training in classrooms so that students would be able to cultivate self-learning and cross-cultural adaptation capabilities. Teachers, having the main role of teaching should also keep up with the pace of culture, understand the subject in depth, participate in training seminars, expand their horizons, and provide students with positive guidance. In addition, foreign teachers can provide useful consultations to students, provide opportunities for students to learn about foreign countries, focus on nurturing students' language skills according to different education and teaching contents, as well as deepen their understanding and grasp of foreign cultures. If there are occasions where foreign students and Chinese students are able to interact, teachers should make full use of this approach to actively stir-up students' enthusiasm or they can encourage both, foreign students and Chinese students to organize cultural activities where these students are divided into different groups for practical activities. Teachers should also use effective and diverse methods to collect and integrate information such as establishing a website, conducting a debate or a mock auction, creating a simulation of an old retail market where bargaining takes place or imitating the setting of United Nations, etc. so that the students' language skills can be improved.

There is a need to advocate diversified training methods by adopting German-English and professional German education methods as well as encourage students to learn English and German bilingually especially for those with some foundation to improve their German language skills. Facing the increasing demand for the use of English, students should be allowed to learn German but not forgetting English. In the early stage of enrollment, self-study for the English test is advocated and the method of joint teaching by Chinese and foreign teachers is embraced to comprehensively cultivate students' English skills in comparing English with German to have an in-depth learning of German which can improve the efficiency of its application. If students are able to master the German language and learn professional knowledge coupled with compound bilingual, their knowledge reserve will be optimized. Majoring in one language while being multilingual helps to ensure that students can undertake and meet the needs of various tasks so that there will be more room for growth and they would be able to take on more social responsibilities. While learning German, it is combined with several professional courses. At higher grades, students can choose suitable courses for in-depth study according to their interests including economic, international trade, accounting, technical German, and other professional courses so that they can fully access the German language from multiple angles, improve social practice skills, and be able to flexibly use the language. Students that are educated in this way can meet the country's requirements for applied talents in addition to nurturing and providing more German-speaking professionals for the country. 
Cooperative education builds a broad platform to interact and collaborate with enterprises and institutions in combination with the actual situation of local colleges and universities. The close collaborations with German enterprises can be carried out to establish a stable internship base for nurturing applied talents according to the needs of industries. Cooperative education is a relatively broad and basic method of nurturing students that has been adopted by many schools today. Therefore, schools are required to have more humane methods when organizing and implementing it so that students are able to apply the knowledge learned from books into practical work which narrows the distance between enterprises and schools. In general, the serious problem of long-term professional employment is also a problem related to the system and thinking. More joint learning or cooperative education models should be implemented to broaden the employment directions of students. Learning German is not only a form of language learning but it is also an innovative attempt in terms of the thinking mode. Students who have gone through the whole learning process are able to display stronger adaptability in enterprises.

Secondly, schools also need to assign more teachers to various enterprises and learning institutions for visitations or to investigate and understand the current situation of the industry as well as the direction of talent training in order to formulate a reasonable talent training plan and ensure the smooth implementation of the curriculum system. In terms of foreign exchanges, there is a need to develop close cooperation with German universities and their cultural organizations, contact various schools to provide personnel and financial guarantees, provide students with more room for development, selectively reinstate advanced foreign cultural knowledge, and implement the latest educational teaching theories. Whether it involves exchanges and cooperation with enterprises and institutions or active expansion and communication with the outside world, they all serve to provide the most advanced knowledge for students in order to improve their comprehensive quality as well as pave the way for them to grow and become talents, hence continuously supplying applied German-speaking talents for China.

\section{Conclusion}

With the "One Belt One Road" initiative, cultural, economic, and political exchanges between China and the countries along the route have expanded. Mastering a country's language and cultural background will help improve the effectiveness of these exchanges. China has put forward higher requirements for applied compound talents, hence the education and teaching staffs of the schools are constantly exploring on how to move toward a broader path. As the bridge between China and Germany, personnel that are engaged in German language-related jobs need to set stricter requirements on their own quality. Due to the extreme shortage of high-quality German translators, the teaching of German translation and training of these translators have received much more attention from schools, experts, employers, and students. However, solving this problem requires coordination and cooperation from many aspects. Under the premise of clear market demand, the macro-level talent training plan and curriculum have been adjusted, translation courses have been reformed in addition to the adoption of scientific, reasonable, and balanced teaching models. Thereby, the shortage of high-quality German translators may improve.

\section{Disclosure statement}

The author declares that there is no conflict of interest.

\section{References}

[1] Li Y, 2014, The Quality of Minor Language Talents and Quality Training Measures Under the Background of "Chinese Culture Going Global" - Taking German as an Example. Tianjin Academy of Social Sciences Press. 
[2] Peng Y, Yang L, 2018, Optimizing the Teaching of German Quality Elective Courses in Colleges in the Background of "One Belt, One Road": Taking German Teaching as a Research Example. The Science Education Article Collects, (3): 190-2.

[3] Bie X, Cheng Y, 2017, How to Walk the Silk Road of German Majors Under the "One Belt and One Road" - A Survey Report on the Employment Status of German Majors in Universities. Yangtze River Series, (17): 80-1.

[4] Xia X, 2019, The Problems and Solutions on the Cultivation of Compound Translators Under the Background of The Belt and Road Initiative. Liaoning Education Research, (01): 103-7.

[5] Wang Y, 2016, Research on the Training of Internationalized Foreign Language Talents Under the Background of "One Belt One Road". Journal Of Higher Education, (9).

[6] Zhao S, 2015, Language Needs for the Construction of "The Belt and Road Initiative" and Its Services. Journal of Yunnan Normal University (Philosophy and Social Sciences Edition), (7). 